\title{
Problematic blue growth: a thematic synthesis of social sustainability problems related to growth in the marine and coastal tourism
}

\author{
Neva Leposa ${ }^{1}$ \\ Received: 20 March 2019 / Accepted: 10 March 2020 / Published online: 1 April 2020 \\ (c) The Author(s) 2020
}

\begin{abstract}
Marine and coastal tourism constitutes one of the largest and fastest-growing segments in tourism. Growth in marine tourism is now furthered through the 'blue growth' imperative, which this article problematises. The paper argues that there are already existing sustainability issues related to the marine tourism sector. These problems could be exacerbated if growth is additionally boosted. Since the social sustainability consequences of the growth of marine tourism are less known in the sustainability science literature, this paper thematically synthesises these types of sustainability problems in particular, as presented in the tourism studies, and brings them closer to sustainability science readers. The cases of cruise tourism, ecotourism, and tourism in marine protected areas, and community-based tourism studies are examined, wherein the latter represents a critical case for social sustainability matters. The paper reports several social and environmental injustices, produced through structural forces, and a manipulated access to natural resources, health services, and healthy environments. Social sustainability issues are most obvious in cruise tourism; however, also tourism in marine protected areas, ecotourism, and community-based tourism are not unproblematic. Thus, blue growth initiatives should be carefully examined and questioned.
\end{abstract}

Keywords Blue degrowth · Marine and coastal tourism $\cdot$ Social sustainability

\section{Introduction}

Marine and coastal zones are highly valued places for tourists to visit. Marine and coastal tourism constitutes one of the largest and fastest-growing segments in the tourism industry. It is estimated that by 2030 , marine and coastal tourism will constitute the largest share (26\%) in the global ocean economy, employing 8.6 Mio. persons (Dwyer 2018).

The EU has recognised seas and oceans as important resources, with the potential to contribute to 'growth'. This type of economic growth, which aims to utilise marine and coastal resources, is called 'blue growth'.

Blue Growth is the long term strategy to support sustainable growth in the marine and maritime sectors as

Handled by Irmak Ertör, The Ataturk Institute for Modern Turkish History, Turkey.

Neva Leposa

neva.leposa@globalstudies.gu.se

1 School of Global Studies, Gothenburg University, Gothenburg, Sweden a whole. Seas and oceans are drivers for the European economy and have great potential for innovation and growth. It is the maritime contribution to achieving the goals of the Europe 2020 strategy for smart, sustainable and inclusive growth. The 'blue' economy represents roughly 5.4 million jobs and generates a gross added value of almost $€ 500$ billion a year. However, further growth is possible in a number of areas which are highlighted within the strategy. (EC 2019)

Coastal and maritime tourism is - along with aquaculture, marine biotechnology, ocean energy, and seabed mininglisted as one of the focus areas with a potential for delivering jobs and sustainable growth: 'It is the maritime contribution to achieving the goals of the Europe 2020 strategy for smart, sustainable and inclusive growth' (EC 2019). To address blue growth, the European Commission laid down a 'Strategy for more Growth and Jobs in Coastal and Maritime Tourism' in 2014. It has furthermore recommended a 'series of actions to boost the sector and support the development of sustainable tourism in coastal destinations' (EC 2014). These actions include the development of an online guide to the main funding 
opportunities available for the sector, promotion of ecotourism, or stimulating innovative management schemes (EC 2014). Thus, in addition to the above-mentioned ongoing trend of growth in the marine tourism sector, this sector is now receiving an additional political boost to grow sustainably.

While the blue growth strategy might appear a wellintended political idea, especially when justified through its ability to 'provide jobs' and considering the types of tourism, which are assumed to be more sustainable (e.g., ecotourism), it is our academic task as social scientists to reflect, ask what such an imperative entails, and evaluate such intentions. Being a rather recent initiative, it is timely to examine the potential implications of the blue growth imperative. Subsequently, it is a more straightforward task to assess the number of jobs marine tourism creates as well as its contribution to the global economy, yet it is more challenging to identify the qualitative social implications of these developments (Hoyt 2001). Since the knowledge concerning the implications of the social sustainability of marine tourism developments is lacking in the sustainability science literature, this present paper focuses on this particular matter.

Sustainability science literature has quite extensively reported on the socio-economic and environmental consequences of, and adaptations to, environmental change, including such change to marine and coastal contexts. For example, studies have assessed the environmental, social, and economic risks (e.g., Rizzi, Gallina et al. 2016), or have spoken about creating resilient coastal communities (e.g., Surjan and Shaw 2008). In this context, tourism is mentioned as an important contributor to the economy and its sensitivity to the environmental changes is recognised (Rizzi et al. 2016). Studies, furthermore, explore how communities and their individuals can be included in planning through a participatory approach (Bello et al. 2016), or how their pro-sustainability agency can be developed (Force et al. 2018). However, the marine tourism sector is also susceptible to social sustainability problems that emerge through tourism developments in coastal and marine environments, which sustainability science literature has rarely reported on. In the tourism literature, such studies exist, but have not been thematically synthesised. Thus, this paper aims to thematically synthesise empirical studies on marine tourism with respect to the existing social sustainability problems. Based on the already existing problems, it first brings this knowledge from tourism studies closer to sustainability literature. Second, it problematises the additional boost in the sector, through the 'blue growth' imperative.

By critically addressing the issues of the social sustainability of marine and coastal tourism development, this paper features a critique of blue growth, i.e., growth in the marine context. Such a critique of growth adheres to one way of understanding 'degrowth' (D'Alisa and Demaria 2014; Ertör and Hadjimichael 2020). Thereby, this paper is thematically linked to a special feature on Blue Degrowth and the Politics of the Sea, which features the problems of the blue growth imperative and calls for rethinking the blue economy.

To present the potential social sustainability problems of marine and coastal growth, I conducted a qualitative thematic synthesis of the tourism studies while extracting only the parts that reveal these issues. Moreover, I analysed and compared the following three expressions of marine and coastal tourism: (1) cruise tourism, (2) ecotourism and tourism in marine protected areas, and (3) community-based tourism.

\section{Method}

The purpose of this study is to outline and analyse social sustainability issues related to marine tourism development, which in turn can challenge the blue growth imperative as such. Social sustainability aspects include aspects of health and well-being, social and environmental justice, social inclusion, and a sense of belonging (Dempsey, Bramley et al. 2011). To conduct a critical study, to feature 'degrowth', literature which speaks about 'problems' and 'issues' related to the above-listed aspects of social sustainability is considered. Moreover, studies taking political economy and political ecology perspectives are appreciated, since their theoretical focus on the power of social actors as well as discursive and material aspects highlights how people, nature, and power are connected in the context of tourism developments (Douglas 2014; Mosedale 2015). Thus, such studies can reveal the critical aspects of social sustainability issues of marine tourism developments.

To narrow down the scope of this paper, I focus on the social sustainability issues that affect the host communities. Moreover, I selected the following three forms of marine and coastal tourism: (1) Cruise tourism, (2) Ecotourism and Tourism in marine protected areas (MPAs), and (3) Community-based tourism. First, cruise tourism has been experiencing rapid growth within the marine tourism industry (Sun, Jiao et al. 2011; Nogué-Algueró 2020). Cruise tourism introduces a high number of visitors at specific times, which makes it quite particular and different from other forms of tourism. Moreover, the literature typically does not (yet) speak of cruise tourism in combination with nature-focused and/or community-based tourism, which allows contrasting and comparing with the other two forms. The second group of articles which I consider are those about ecotourism and tourism in MPAs. These forms are different in terms of regulations in place, but in both cases, the environmental aspects of sustainability (Almeyda et al. 2010) and commonly also social sustainability aspects are considered (Wood 2002; Voyer et al. 2012). The third, community-based tourism was chosen for its consideration of the interests of the community. It strives towards equal distribution of the benefits, and the costs, among all the participants, while not excluding 
other ecological and economic principles of sustainability (Salazar 2012).

The three versions of tourism listed above were chosen to compare their potentially differing degrees of consideration in relation to social sustainability matters. Cruise tourism represents an extreme case, since the social sustainability issues are assumed to be overlooked in that particular case. On the other hand, community-based tourism provides a critical case, as this particular type extensively considers the importance of social sustainability (see Flyvbjerg 2005 for the discussion on the extreme and critical cases). Consequently, if social sustainability issues are found even in this particular type of tourism, the type that is supposed to be less problematic, it is most likely that growth in other types of marine tourism will be problematic.

The literature was analysed by conducting a 'thematic synthesis', following Thomas and Harden (2008) who suggest that the common method of analysis of primary research, such as thematic analysis, can be successfully applied also in systematic reviews. Thematic analysis (a common qualitative method) guides a researcher to identify and develop themes in the analysis of the primary qualitative data (Boyatzis 1998). A thematic synthesis has guided me to develop and analyse themes by reviewing the existing empirical studies in tourism research. In particular, the analysis was conducted over the following four steps, inspired by Thomas and Harden (2008), i.e.. searching, selecting, extracting, and thematically synthesising.

\section{Searching}

The search for appropriate tourism studies was carried out using the Scimago Journal \& country rank website, which produced a list of 107 tourism journals. 23 journals were found relevant. The subjects of leisure, sport, marketing, hospitality, or management journals were excluded. Papers in the selected tourism journals were then searched for (between 2000-2019) using the keywords: 'community', 'marine', 'island', 'water', 'coast', 'beach', 'sea', 'ocean', 'park/MPA/reserve/conservation', 'development', 'growth', 'cruise', 'ecotourism', 'social', 'sustainability', 'political ecology', 'political economy', 'justice', 'belonging', 'inclusion', 'participation', 'health', 'well-being', 'stress', and 'impact'.

\section{Selecting}

Papers were selected using the following four criteria:

1. The empirical study concerns marine-based tourism and/or marine-based resources. In this respect, I first considered studies that discussed marine tourism activities, such as visiting the coast, boating, kayaking, diving, and cruising. Second, I also included papers where tourism activities were perhaps land-based (e.g., souvenir making), but where there was a connection to marine resources. For example, souvenir makers who previously sustained themselves through fishing.

2. The topic is consistent with the selected focus in the present review paper: cruise tourism, ecotourism, tourism in marine protected areas, and community-based tourism.

3. At least one of the social sustainability aspects is discussed in the paper, i.e., social inclusion, belonging, well-being, and justice.

4. The paper identifies social issues/problems related to marine tourism. Papers identifying merely positive aspects were excluded.

Less than 5\% of all the hits using the search have satisfied the above-listed criteria. Around 55 papers were saved. From those, I selected the papers that satisfied all the above-listed criteria. In some cases, determining whether the paper is a 'marine case' paper or not was difficult, since not many articles speak of 'marine tourism' as such, but are still relevant. Moreover, quality triumphed quantity. I applied a principle of conceptual saturation (Thomas and Harden 2008) to assure the variety of issues is covered. That was done in the second stage when papers were read and themes were defined. Moreover, I used Google Scholar to extend the search and find additional studies, if it turned out, the variety of topics is not covered in tourism journals. This was the case for mental and physical health and environmental justice. I kept about 20 papers for thematic synthesis.

\section{Extracting}

Only the relevant parts of the papers, those related to the social issues of marine tourism sustainability, were extracted into a table. The extracts mattered more than the overarching argument of the article-as these were purposefully selected for this paper.

\section{Thematically synthesising}

Thematic synthesising was done in two steps using a table in a Word document. First, the extracts were summarised, and in the next column, descriptive themes were developed. Second, the synthesis was done by categorising and grouping the types of issues identified by the particular papers. I marked the themes using colours to identify the same themes. Overarching themes emerged through this process, going back and forth from seeing both details and the larger story. 


\section{Findings}

Findings are organised around three themes for the three chosen forms of tourism (cruise, ecotourism, and tourism in MPA, and community-based tourism). The three themes are: (1) structural issues: these include the structural forces of social and market relations, (2) infrastructure, access, and daily life: this category covers the physical and social changes and its effect on the daily life of the residents, and (3) well-being: this category includes emotional and physical well-being experienced by host residents as a consequence of the marine tourism developments.

\section{Cruise tourism}

According to the reviewed studies, cruise tourism can cause more problems for the port communities than it benefits them. The port residents experience stress and disruption to their daily routines as a result of the rapid growth. Additional problems include unforeseen externalities (such as cleaning, provision of public services, and adjusting and maintaining the infrastructure) and the damage caused to the marine environment together with lack of planning, dispossession, and prevention of access to the port.

\section{Structural issues}

The structure of marketing related to cruise tourism reaffirms the power of powerful actors and leaves the local communities without many options to penetrate and compete on the market. Cruise tourism is embedded in the global market and it can escape national and international regulations:

Cruises represent the paradigm of globalisation: physical mobility, international capital that can be relocated anywhere and at any time, crews coming from different countries at the same ship [...] no national or international regulations, marine registrations optimally selected. (Brida and Zapata-Aguirre 2009: 213)

Cruise touristic destinations can transform into a recognisable 'product' by the privatisation of islands to serve cruising purposes (Brida and Zapata-Aguirre 2009) or by introducing recognisable services to the port towns. This diminishes the port's (prior) identity. For example, at the port of Key West, Florida, several locally owned shops and restaurants were transformed into franchises that can be found in other port destinations around the world. ' $(A)$ cross the street (from your hotel) you see Burger King, then Eckerd's Drug, a Hard Rock Café and other stores and shops that are at every cruise ship destination around the world. At a certain point, wouldn't you start scratching your head and say I've been sold a bill of goods? Where is the easygoing, laid-back relaxed atmosphere I was sold?' (Hritz and Cecil 2008: 176-177). This quotation also touches upon the importance of advertising. Besides advertising for the cruise as such, the land-based activities are also advertised (for a price) on board. Moreover, the activities, which can omit the port town, are often also sold on board: 'At the port, the vans fill up with cruise passengers and take them to other areas instead of Falmouth' and 'Most tourists get booked before leaving the port and provide nothing for the people of Falmouth.' (Jordan and Vogt 2017: 536-537).

This structure of marketing (using specific marketing channels) and advertising (paid), which are tightly linked to the global cruise business, through support from a strong group of lawmakers, can leave the communities emptyhanded without much opportunities to gain benefits from cruise tourism (Brida and Zapata-Aguirre 2009).

\section{Infrastructure, access, and daily life}

Cruise tourism affects physical infrastructure, compels displacement, and requires maintenance of the infrastructure and services, while it can deny access to the locals and can impel port residents to change their daily routines.

The development of cruise tourism often requires a physical re-structuring of the coast. Due to the construction of the port, the locals can be marginalised and displaced. For example, in Honduras, the initiation of cruise tourism placed elite Honduran and foreign investors in conflict with a local Afro-indigenous population. According to the community members, when constructing the port, the traditional territory of the indigenous community might have been illegally obtained to give space to the cruise operations (MacNeill and Wozniak 2018).

Regarding social relations and daily life, the development of cruise tourism can increase the cost of living, add to crowding and congestion at particular times, due to which residents often change their daily routines (Marušić et al. 2008; Jordan and Vogt 2017). While some locals claim cruise tourism contributes to the vibrancy downtown (Hritz and Cecil 2008), they also point out several issues. Dubrovnik residents, for example (Marušić et al. 2008), are changing their daily routines to cope with the crowdedness at particular times. While they voice the need for improving the traffic and tourist flow management, they still express support for cruise tourism (ibid.). A similar problem of crowding and congestion is mentioned by Falmouth residents (Jamaica): 'It is difficult to drive in and out of Falmouth due to all the one-way streets created when the cruise port was built.' (Jordan and Vogt 2017: 537). Moreover, the residents of Falmouth are denied access to the port. When 
ships are in town, it is difficult for them to 'get things done', they express.

\section{Well-being}

Cruise tourism is found to also negatively impacting the health of local residents. Seventy eight of the Falmouth residents $(N=362)$ perceived stress as related to the development of the new cruise port. Several stressors are described already above, such as congestion, services, increased cost of living, and lack of job provision for the locals. The stressors perceived by most of the residents are having their expectations unfulfilled: '[The cruise company] said there would be benefits from the port and we're not seeing them.' (Jordan and Vogt 2017: 535). This relates to a lack of job opportunities for the locals, lack of visits of tourists to town, and residents denied access to the port. As already above-mentioned, the increase in the cost of living, congestion, displacement, and access to services, cause stress. For example, 'When the ship is in port the entire water system doesn't work'. (ibid: 539). In addition, the residents are negatively affected by noise and smell: 'They blow the horn for 15 min when they arrive and leave.' and 'We can smell the sewage from the ships every time they come in, sometimes it's extremely bad.' (ibid: 538-539). Moreover, Seidl et al. (2006) stress that the degradation of the water and air due to cruise tourism creates public health concerns ashore and generates a need for water and waste management.

Due to social, in addition to environmental consequences of cruise tourism (there is an overlap with social, e.g., sewage, noise, and air pollution causing a hazard to health), several authors ask whether the benefits of cruise tourism outweigh the costs (e.g. Brida and Zapata-Aguirre 2009). Seidl et al. (2006) are hesitant and argue for a smaller, 'pocket', cruises instead. Other authors call for regulations, marketbased solutions, and social responsibility/commitment of cruise operators to be responsible and assure inclusion and protection of communities (Klein 2011). Some suggestions are donation of investment funds and/or providing a free area into the ports for market transactions between tourists and locals. If such, or similar, actions are not taken, cruise tourism is likely to benefit merely the foreign investors and local elites MacNeill \& Wozniak (2018) conclude.

\section{Ecotourism and tourism in MPAs}

Ecotourism and tourism in MPAs are commonly presented as a 'win-win' scenario-a situation where the environment is preserved, while the locals can sustain their livelihoods, through an alternative (tourism-focused) earnings (Meletis and Campbell 2009). However, empirical cases described below show that the jobs are not necessarily provided for the locals and the profits are not necessarily staying where they are created. Ecotourism can create environmental injustices that disproportionally marginalise and impact communities. MPA regulations can conflict with or induces changes in the locals' everyday lives and the promised development affects the tourist areas rather than the neighbouring communities, inducing differentiation and social and environmental injustice and inequality.

\section{Structural issues}

The first structural social issue related to tourism in MPAs relates to re-regulation, which affects different groups, differently. For instance, in the making of Galapagos Marine Reserve, the regulatory and administrative re-structuring restricted fishing for small-scale fisheries in the reserve. The local fishers were instead encouraged to find employment on larger vessels, beyond Galapagos Marine Reserve (Mathis and Rose 2016). Sometimes prohibitions are focused on the gear type or the type of fishing practice. In Mpunguti Marine National Reserve (Kenya), 'locals are still allowed to do spin fish and to use fish traps on a subsistence level' (Job et al. 2013: 26). Yet, in either case (when softer or harder regulation is in place), the base of scientifically derived knowledge serves as a means of introducing new regulations. One of the consequences of this process, inter alia, results in the fact that the regulations in MPAs have to work with or compete with the informal institutions. In Madagascar, for example, informal institutions (e.g., fady) can impose a fishing prohibition on certain days or in certain secret areas (Cinner et al. 2009; Andriamarovololona and Jones 2012). After an MPA is introduced and tourists are visiting the area, such a double stream of institutions (formal and informal) can leave local sea-users feeling conflicted. In addition, tourists may not be aware of the local informal institutions.

The imperative for increasing MPAs area is stipulated by influential global NGOs and private-public collaborating actors, which ideas the local leaders adhere to (Duffy 2006). Moreover, through re-regulation, the governments might gradually relinquish the decision-making leverage over the marine territory and its resources. This is commonly described as 'ocean-grabbing' (e.g., Mallin et al. 2019).

Second, structural change can imply social injustice when it comes to MPA earnings distribution and job provision from tourism for the local actors. As seen in Brondo (2015), jobs in Honduras, which could be done by local people, are given to the paying tourists from the North instead. Moreover, in Galapagos growth in tourism introduced a highly complex structure of workers and businesses. Workers come from different areas and business has their headquarters in different places. In such an assemblage, it becomes unclear where the money is coming from and where it goes. Thus, profits from tourism do not necessarily 'stay on the 
island' (Mathis and Rose 2016). In the case of Kenya Island MPA, the MPA entrance fee earnings end up in the Nairobi headquarters and also park employees live on the mainland: 'Therefore park employment has no economic impact on Wasini Island at all.' (Job et al. 2013: 26). Moreover, since the park receipts are not returned to the park, the park suffers a lack of funds for the infrastructure, maintenance, equipment, and patrolling (Job et al. 2013).

\section{Infrastructure, access, and daily life}

MPA creation often entails certain infrastructural transformations and shapes access to resources for the local people. As Hampton et al. (2018) show, the development of tourism paved way for the coastal tourism infrastructure through which it obscured work and livelihoods of local people. While tourism service work was on the rise, it excluded Bajau people's sea-based work (fishing) for sustaining their lives. This exclusion materialised through physical (material) restriction, as tourism infrastructure converted the coast to semi-permanent moorings, which hindered access to the coral reefs. Coral reefs have instead been increasingly designated for tourism and conservation, affecting work of the Bajau people. Moreover, development of the areas and provision of services can become unequal. While focus can be on maintaining MPAs regulated, in other areas, the upscale housing and private beaches can be constructed by bypassing laws or paying fine for cutting down mangroves (Brondo 2015). The infrastructure can be more available for the tourist areas, while the town lacks potable water, a sufficient education system and healthcare:

Within the past 10 years, and supported by the Ecuadorian government, the pier has transformed from a simple port to a brilliantly colourful boardwalk where tourists walk along geometrically patterned streets to see the vibrant travel agencies, souvenir shops, hostels, and restaurants. Tourism generates income for residents, yet locals feel as though money continues to be allocated to tourism-related development projects while the inhabitants often lack basic services. (Mathis and Rose 2016:72)

Ecotourism typically builds upon geographic isolation, as such places can appear more 'natural' and attractive for this type of tourism (Meletis and Campbell 2009). However, the lack of easy transit can make services, such as waste management, very difficult. The need for those increases due to the high growth of ecotourism. In addition, solid waste can negatively impact conservation efforts, since the waste on the beach affects turtles' fitness negatively, to say the least. Meletis and Campbell (2009) thus argue that solidwaste crisis is an example of environmental injustice, despite ecotourism:
Our case study is one in which residents identify the solid waste crisis as an environmental injustice, despite the benefits of ecotourism, and despite the village's relative wealth in its region. While the benefits of ecotourism are real, numerous, and much appreciated in Tortuguero, this does not change the perceived injustice of the solid waste crisis. (Meletis and Campbell 2009: 770)

Moreover, due to tourism, residents can perceive the risk of the facilities being overused. The need for supply of water, electricity, and waste management needs to be adjusted to the speed of growth of tourism needs: 'Sabang shows very little evidence of proper planning. The streets and alleys are narrow.' (Catibog-Sinha 2013:112).

These transformations also link with changes in social relations and affect locals' daily lives. In the case of Galapagos (Mathis and Rose 2016), a self-sufficient farming and fishing economy transformed into one that relies on revenue from tourism. The view of nature has been transformed from 'useful and edible' to one which is an attraction for tourists. Some, who have adjusted to the new economy and transitioned their careers from fisherman to tourism workers report having higher earnings to support their families. For others, things are more difficult. The people of Bajau lead a migratory, sea-oriented life and their livelihoods are sea-based. Thus, changing their lifestyle and everyday lives to serve tourists on land is difficult for them (Hampton et al. 2018). Moreover, as livelihoods of the local community are more tightly linked to tourism, a higher dependence on the tourism market and vulnerability to its fluctuations is created (Catibog-Sinha 2013).

\section{Well-being}

A few studies study the health and well-being impacts of marine tourism for ecotourism and MPA destination residents. Studies mention environmental risks though and these relate to human health. There is also inequality in regard to access to healthcare and maintaining a healthy everyday life (clean water, land). While the facilities and services can be more accessible closer to the tourism areas, they appear lacking for locals, especially those residing further from the park. Mathis and Rose (2016) observe that the development of the services intended for tourists trumps that for locals, who lack access to potable water and sufficient healthcare. Brondo (2015) stresses that there is an issue of environmental justice related to health hazards. Some locals, due to the increasing prices of coastal land, purchase a cheaper, for them more accessible, piece of land. However, in those places, the proper water and sewage system is not in place, which raises concerns around illnesses: 'The problem with Camponado is that they never put the water pipes [in]. Like 
all the management of the black waters and grey waters, and that's a bomb for Utila. You sometimes can walk on the main road in town and you can feel the smell, and it comes from Camponado.' (Brondo 2015: 1417). More generally, Catibog-Sinha (2013) reports that some residents of Puerto Galera (a reserve in Philippines) express dissatisfaction with the sewage treatment facilities. It cannot catch up with the needs created by the fast development of tourism, which contributes to low water quality and health hazards (ibid.).

While residents can be welcoming towards tourism development, they — as identified above - point out the unequal distribution of the services, facilities, and natural resources in or beyond MPA areas. To increase participation of the community in the development of tourism, a form of 'community-based' tourism has been suggested, which I turn to in the following.

\section{Community-based tourism}

Tourism developments can have a negative impact on some groups of local residents more than others. Participation in development and decision-making can also vary. In Pari (Indonesia), local residents were included in the tourism developments. They run cafes, shops, boat/bike rentals, and provide homestays (Kinseng et al. 2018). Yet, one can ask: which groups of people are included and which are not? Who benefits more? Authors who do investigate, this show that there are differences. In Labuan Bajo, tourism growth has affected women more than men, since women are responsible for domestic water provision. Women are also not included in the decision-making (Cole 2017). In response to the problems, a suggestion emerged, to include locals in tourism developments (planning), framed as community-based tourism (CBT), where:

initiatives are planned in conjunction with members of the local community who participate in decisionmaking processes and benefit equally from the positive effects of tourism. A tourism model of this type should take into account the characteristics and idiosyncrasies of the island to prevent, insofar as possible, undesirable outcomes, while providing an avenue for sustainable development. (Sánchez-Cañizares \& Castillo-Canalejo 2014: 220)

\section{Structural issues}

Initiatives for CBT show that structural, financial barriers, as well as skills, can hinder the participation of the communities in tourism developments and decision-making. In Cape Verde, efforts are being made for the community to participate in the development of sustainable tourism. However, these efforts are constrained by the local communities' lack of access to capital/funding, lack of training opportunities, and lack of governmental support. While companies express a commitment to hiring local staff, among the formed panel of experts (tourism service providers), on the level of management, more than half are Europeans (SánchezCañizares and Castillo-Canalejo 2014). Mitchell and Reid (2001) examine CBT in the Andean community of Taquile Island in Peru. They report a high level of citizen involvement in tourism-related decision-making. Public views are taken into account and they claim that economic benefits are shared since the industry offers work to locals and ownership is mostly local. However, sometimes work is part-time or occasional. Moreover, women have a marginal role in community politics and decision-making in general and in tourism. Structural issues of inclusion and participation are tightly linked to the decision-making which goes beyond, but it also affects tourism.

In Thailand, ecotourism was initiated and furthered by foreign expatriates (Kontogeorgopoulos 2005). Foreign expatriates made Thailand their permanent home and started with the sea kayaking and trekking companies in Phuket. Thus, the control and direction for tourism also rest with them. However, locals still have some management positions. According to Kontogeorgopoulos (2005), since locals and communities lack business skills, status, and power, the foreign control of ecotourism facilitated high-paying, secure, and rewarding jobs for the locals. Thus, while communitybased tourism provides local employment, that comes at the expense of control and initiation.

\section{Infrastructure, access, and daily life}

In terms of access and livelihoods, one suggestion in the context of MPAs, which considers communities' livelihoods, is, for example, that the locals can exchange their fishing rights with the diving user fees (e.g., Brunnscheweiler 2010). However, in any case, an introduction of tourism activities induces a shift in livelihoods and skills, since tourism activities typically replace the host communities' prior occupations. Such a change of livelihoods can lead to the loss of former skills (e.g., fishing) and can result in higher dependence on tourism as the main source of income. This can make locals more vulnerable to the tourism market fluctuations (Lasso and Dahles 2018). Moreover, these changes also redistribute the way space is used and by whom. The case from Indonesia shows that once the local people's fishing vessels were sold, and working with wood products and crafting skills began to replace fishing, the void at sea was swiftly occupied by the neighbouring villagers. This, together with discontinuation of upholding the skills, may make it difficult to potentially resume the activity, if such diversification may be needed (ibid.). Moreover, as the 
traditional livelihoods are replaced the knowledge and previous type of accompanying social relations can also vanish. Locals also reported this to be one of the negative consequences of tourism (decline in social relations), as if they are willing to help one another less (Kinseng et al. 2018).

According to Kontogeorgopoulos (2005), some employees in the ecotourism company in Phuket (Sea Canoe) belong to ethnic and religious minorities. Working for the company increases their social status and provides them with an opportunity for a more egalitarian and casual atmosphere: 'Working for Sea Canoe not only enhances the status but also allows guides to suspend or reverse normal patterns of stratification. Psychologically, the casual and egalitarian atmosphere aboard Sea Canoe escort boats frees Thai guides from rigid social norms.' (Kontogeorgopoulos, 2005:13). However, that comes at the expense of social cohesion and harmony as they have to deal with new competitors, 'copycats' (e.g., an enterprise which mimics another enterprise in its main focus), and their illegal and unethical practices.

\section{Well-being}

On Pari Island, Indonesia, the locals report an improvement in terms of access to food, clothing, building materials, education, and health, as well as safety, as a result of tourism development (Kinseng et al. 2018). In Phuket, Thailand, the employees associate 'fun' and 'freedom' with their work, as if they can have fun at work. However, there is also a level of insecurity felt as their work depends on maintaining the environment preserved. While that also motivates them to preserve the environment and act as environmental stewards, it is not all dependent on them, the area is becoming crowded and the expansion is unregulated (Kontogeorgopoulos 2005). In terms of other health-related aspects, more data are needed to determine who has easier access to the services and who may not, and whose well-being suffers more.

Community-based tourism promises that the efforts of community participation can also serve the economic, environmental, and social interests of host communities. While it tends to pay attention to the social aspects of sustainability, these interests sometimes come at the expense of ecological sustainability, loss of control or loss of social cohesion, and harmony.

\section{Conclusions and discussion}

The aim of this paper was to outline the potential social sustainability problems of blue growth in tourism by drawing on the empirical evidence from the tourism studies. I particularly focused on the three specific types of tourism: cruise tourism, ecotourism, and tourism in marine protected areas, and community-based tourism in marine and coastal environments. Three main findings are discussed below. The first finding relates to the difficulty of clearly discerning the social sustainability issues related to marine tourism developments. Second, the range of the social sustainability issues covered in the literature is limited, especially related to environmental justice, and even more so, well-being. Third, there is a difference between different types of marine tourism. While cruise tourism is, as expected, most problematic, even tourism in marine protected areas and community-based tourism cases are imbued with issues of inequality, vulnerability, dependency, and power imbalance. These findings question the 'blue growth' imperative.

First, I would like to point out that it is extremely difficult to discern all the possible social sustainability issues related to marine tourism growth. When compared to environmental and economic aspects of sustainability, social issues are less straightforwardly identified. It is also more difficult to establish the motivation for addressing them, especially when actors are unknown or operate at a distance. For example, as shown in Kontogeogropoulos (2005), tourism workers are motivated to preserve the environment, since their future employment depends on tourist visits. The motivation to address social issues appears less driven by a 'utilitarian' logic. When it comes to social equality and fair distribution of sharing tourism revenues, it is the underpinning ethics of the business operators at play. While the tourism benefits from the local places, if the actors are operating at the distance, as in cruise tourism (Brida and Zapata-Aguirre 2009) or even in cases of MPAs (Brondo 2015; Job et al. 2013; Mathis and Rose 2016), it is much more difficult to establish a fair/proportional distribution of the benefits. This empirical finding should serve as a methodological reminder, for researchers working in the sustainability field, to observe how, where, by and for whom the benefits and negative consequences are created. Moreover, where, how, and by whom are these benefits and consequences shared. Tracing the actors and the benefits/consequences can be a useful methodology when studying social sustainability topics in general.

Second, social sustainability issues related to tourism developments are very complex and broad and the existing tourism studies only partially cover all the possible aspects, such as social and environmental justice, social inclusion, belonging, and health and well-being (Dempsey, Bramley, et al. 2011). Social and environmental justice and social relations and cohesion are somewhat covered topics, even though the authors rarely refer to the concept of 'environmental justice' as such. On the other hand, studies on wellbeing/health among host communities are rare. Sustainable tourism literature in general and marine tourism literature in particular report on economic, and to some degree healthrelated concerns related to tourism developments, while 
the personal mental wellbeing aspects for the host residents are understudied. Jordan, Spencer et al. (2019) argue that psychological outcomes, such as emotions and stress experienced by the host community residents, are overlooked in tourism literature. They develop models for studying the relationship between tourism impact, emotions, and stress. Tourism and leisure researchers have been reporting the psychological and mental well-being benefits of activities for the ones pursuing the activities (e.g., Hanna et al. 2019). However, empirical studies with a focus on emotional wellbeing and stress that the host community residents experience are extremely rare. One rare example is Jordan and Vogt (2017), analysed in this review, who elaborates about stressors felt by the residents affected by cruise tourism. There is a whole range of aspects that still need to be studied, not the least, the stress and emotions of people living in or near the marine protected areas. This observation supports the first finding. It is difficult to discern social sustainability related to further marine tourism developments if some aspects have not been sufficiently studied. There is an indication that there might be a wider range of potential problems, which have not been recognised and acknowledged enough —one being the stress on the host communities (Jordan and Vogt 2017). In addition, the literature reviewed is more commonly from the global south geographical places (see Table 1), and thus, the issues within the global north remain less known. Moreover, there is a wider range of different forms of 'marine tourism' that cannot be spoken about uniformly, which leads me to the third finding.

Third, when comparing cruise tourism, ecotourism, and tourism in MPAs and community-based tourism in respect to social sustainability (social and environmental justice, social relations, cohesion, and wellbeing), cruise tourism appears most problematic. However, neither are other forms unproblematic.

In terms of justice, empirical studies rarely use concept names such as 'social justice' or 'environmental justice'. However, studies that examine environment-tourism-livelihoods, or simply explore the industry from a critical perspective do reveal aspects of justice/injustice. Environmental justice refers to fair treatment regardless a position in a society and a right to clean environment (Beretta 2012), while social justice refers to a fair access to wealth, health, assets, participation, or opportunities (UN 2006). In regard to social and environmental justice, I recognise cruise tourism as the most problematic. A covert, yet important case of injustice can be seen by combining findings from studies of Brida and Zapata-Aguirre (2009) and Jordan and Vogt
Table 1 Thematically synthesised literature

\begin{tabular}{|c|c|c|c|}
\hline No & Theme & Authors & Case geographical area \\
\hline \multicolumn{4}{|c|}{ Cruise tourism } \\
\hline 1 & & Brida and Zapata-Aguirre (2009) & Not geographically specific \\
\hline 2 & & Hritz and Cecil (2008) & port of Key West, Florida, USA \\
\hline 3 & & Jordan and Vogt (2017) & Falmouth, Jamaica \\
\hline 4 & & MacNeill and Wozniak (2018) & Trujillo, Honduras \\
\hline 5 & & Marušić et al. (2008) & Dubrovnik, Croatia \\
\hline 6 & & Seidl et al. (2006) & Caribbean, Costa Rica \\
\hline 7 & & Klein $(2011)$ & Not geographically specific \\
\hline \multicolumn{4}{|c|}{ Ecotourism and tourism in MPAs } \\
\hline 8 & & Meletis and Campbell (2009) & Tortuguero, Costa Rica \\
\hline 9 & & Mathis and Rose (2016) & Galapagos Islands, Ecuador \\
\hline 10 & & Job and Paesler (2013) & Wasini Islands, Kenya \\
\hline 11 & & Brondo (2015) & Honduras \\
\hline 12 & & Hampton et al. (2018) & Malaysia \\
\hline 13 & & Catibog-Sinha (2013) & MAB Reserve, Philippines \\
\hline 14 & & $\begin{array}{l}\text { Cinner et al. (2009), Andriamarovololona } \\
\text { and Jones (2012) }\end{array}$ & Madagascar \\
\hline \multicolumn{4}{|c|}{ Community-based tourism } \\
\hline 15 & & $\begin{array}{l}\text { Sánchez-Cañizares and Castillo-Canalejo } \\
\text { (2014) }\end{array}$ & Boa Vista in Cape Verde \\
\hline 16 & & Mitchell and Reid (2001) & Peru \\
\hline 17 & & Lasso and Dahles (2018) & Comodo Islands, Indonesia \\
\hline 18 & & Kinseng et al. (2018) & Indonesia \\
\hline 19 & & Cole (2017) & Labuan Bajo, Indonesia \\
\hline 20 & & Brunnschweiler. (2010) & Fiji \\
\hline 21 & & Kontogeorgopoulos (2005) & Phuket, Ao Phangnga, Thailand \\
\hline
\end{tabular}


(2017). Brida and Zapata-Aguirre (2009) demonstrate the power of globally run marketing channels of the cruise industry. When taken together with the port town residents' perspective, provided by Jordan and Vogt (2017), this gives us a more holistic understanding of how port residents are marginalised. Due to various material, financial, and networking obstacles (e.g., physical access to the port; lack of access to specific marketing channels), they become less able to penetrate the cruise market and cannot compete with the more powerful global actors. Jordan and Vogt (2017) and MacNeill and Wozniak (2018) also show how the locals can be dispossessed when the port is built and how their access to the port is restricted.

Issues of social and environmental injustice are also pertinent in MPAs. As Brondo (2015) and Job et al. (2013) show, locals represent a marginalised group of the workforce in the presented MPA. Brondo (2015) also shows injustice in terms of access to a healthy environment for the marginalised individuals who cannot afford a property where the water management is sufficient. Moreover, even ecotourism cannot be assumed unproblematic. Meletis and Campbell (2009) show that the residents near ecotourism are experiencing the waste problem as a form of environmental injustice. Somewhat fewer issues are reported in cases of community-based tourism; however, even in those cases, some groups of people still report problems. Especially women, for example, can be marginalised and not included in decision-making (Mitchell and Reid 2001).

In terms of social relations, some studies report a change in social relations due to tourism (Kinseng et al. 2018). However, it is difficult to clearly identify the responsibility of tourism, or recognise these problems as distinct from other types of problems Kontogeorgopoulos (2005) for example describes that through ecotourism activities, employees can gain social status and mobility, which may happen at the expense of social cohesion and harmony-since competition for resources becomes stiffer. However, conflict over natural resources and problems of social relations can also exist without tourism activities taking place (e.g., Castro and Nielsen 2003). Some authors report a loss of social relations as they switched from fishing to tourism (Kinseng et al. 2018); however, new occupations also bring new social relations. In addition, through marine tourism developments, the meaning of the sea can become more variant, i.e., in comparison with the previous understandings of the sea, we can add that it is a place of resources, of fun and of enjoyment (Mathis and Rose 2016; Kontogeorgopoulos 2005). Yet, it remains unclear if it is equally 'fun' for the locals as for the tourists. Moreover, tourism evidently shapes local peoples' everyday lives through a change of infrastructure, an influx of cruise visitors, or due to regulated access. This appears to be most problematic in cases of cruise tourism (Jordan and Vogt 2017) and in some cases of MPAs (e.g.,
Mathis and Rose 2016), depending on the level of locals' engagement and rule makings. In cases of MPAs, ecotourism, and community-based tourism, an emerging problem is also loss of skills and decreased diversification-increased dependence on tourism and its fluctuations (e.g. Lasso and Dahles 2018). This is one of the sustainability concerns that resilience studies typically raise (e.g., Cinner and Randriamahazo 2009). Some aspects of social sustainability are overlapping with environmental sustainability; this is clearly the case for health aspect, discussed below.

The health of host communities is the least discussed aspect of tourism literature. Some studies do, however, mention health as related to access to health services (e.g., Mathis and Rose 2016). Moreover, in the reviewed literature, identified social and environmental injustices can harm emotional and physical health. Such a link is clearly drawn in Jordan and Vogt (2017), in the case of cruise tourism and in some cases of MPAs (e.g., Brondo 2015). We can assume that the lack of access to potable water and access to health services for the locals near MPAs (Brondo 2015; Mathis and Rose 2016), a problem of solid trash near ecotourism (Meletis and Campbell 2009), exposure to cruise noise (Jordan and Vogt 2017), can have negative health consequences for the host communities. More studies are needed, however, in particular, on potential stress-related well-being issues, as experienced by the host communities.

Finally, this paper reviewed the marine tourism literature with respect to its social sustainability issues related to blue growth. While blue growth imperative is commonly justified through job provision, development, and well-being, this study shows that such links cannot be assumed-at least not equally, for all involved. While some, more powerful individuals who can 'play the tourism game', whose skills are suitable, can benefit more from such developments, the individuals from a lower social classes, whose lifestyles might not be compatible with tourism, can lose as a result of this development. As shown in the paper, blue growth can lead to social and environmental injustices. Moreover, the distribution of gains and losses depends on the context, type, and form of marine tourism. According to this review, the negative consequences of blue growth appear most prevalent in cases of cruise tourism. To counteract, Seidl, Guiliano, et al. (2006) suggest encouraging 'pocket' cruises over the mass cruising tourism. However, we also should not be oblivious to the problems of the developments of MPAs, ecotourism, or community-based tourism. Here, the social consequences of marine tourism developments might be less obvious as they can show beyond the borders of MPAs or in the general environment where ecotourism takes place. One way to limit the negative consequences is by laying down suitable regulations and by encouraging tourism operators to work in an inclusive and fair manner. We researchers, on the other hand, can follow these progressions by ideally taking 
in both micro- and macro-perspectives, or by combining different studies for a more complete story about potential social sustainability problems related to blue growth and possible solutions to prevent those.

Acknowledgements Open access funding provided by University of Gothenburg.

Open Access This article is licensed under a Creative Commons Attribution 4.0 International License, which permits use, sharing, adaptation, distribution and reproduction in any medium or format, as long as you give appropriate credit to the original author(s) and the source, provide a link to the Creative Commons licence, and indicate if changes were made. The images or other third party material in this article are included in the article's Creative Commons licence, unless indicated otherwise in a credit line to the material. If material is not included in the article's Creative Commons licence and your intended use is not permitted by statutory regulation or exceeds the permitted use, you will need to obtain permission directly from the copyright holder. To view a copy of this licence, visit http://creativecommons.org/licenses/by/4.0/.

\section{References}

Andriamarovololona MM, Jones JP (2012) The role of taboos and traditional beliefs in aquatic conservation in Madagascar. In: Pungetti G, Oviedo G, Hooke D (eds), Sacred species and sites: advances in biocultural conservation, pp 207-217

Almeyda AM, Broadbent EN, Wyman MS, Durham WH (2010) Ecotourism impacts in the Nicoya Peninsula, Costa Rica. Int J Tourism Res 12(6):803-819

Bello FG, Carr N, Lovelock B (2016) Community participation framework for protected area-based tourism planning. Tour Plan Dev 13(4):469-485

Beretta I (2012) Some highlights on the concept of environmental justice and its use. e-cadernos CES (17)

Boyatzis RE (1998) Thematic analysis and code development: transforming qualitative information. Sage Publications, London

Brida JG, Zapata-Aguirre S (2009) Cruise tourism: economic, sociocultural and environmental impacts. Int J Leisure Tour Market 1(3):205-226

Brondo KV (2015) The spectacle of saving: conservation voluntourism and the new neoliberal economy on Utila Honduras. J Sustain Tour 23(10):1405-1425

Brunnschweiler JM (2010) The Shark Reef Marine Reserve: a marine tourism project in Fiji involving local communities. J Sustain Tour 18(1):29-42

Catibog-Sinha C (2013) Island tourism in a UNESCO-MAB Reserve (Philippines): impacts, risks, and challenges. Asia Pac J Innovat Hosp Tour 2(2): 105-121

Castro AP, Nielsen E (eds) (2003) Natural resource conflict management case studies: an analysis of power, participation and protected areas. Food and Agriculture Organization of the United Nations, Rome

Cinner J, Fuentes MM, Randriamahazo H (2009) Exploring social resilience in Madagascar's marine protected areas. Ecol Soc 14(1).

Cole S (2017) Water worries: an intersectional feminist political ecology of tourism and water in Labuan Bajo, Indonesia. Ann Tour Res 67:14-24

D'Alisa G, Demaria F, Kallis G (eds) (2014) Degrowth: a vocabulary for a new era. Routledge
Dempsey N, Bramley G, Power S, Brown C (2011) The social dimension of sustainable development: defining urban social sustainability. Sustain Dev 19(5):289-300

Douglas JA (2014) What's political ecology got to do with tourism? Tour Geograph 16(1):8-13

Duffy R (2006) Global environmental governance and the politics of ecotourism in Madagascar. J Ecotour 5(1-2):128-144

Dwyer L (2018) Emerging ocean industries: Implications for sustainable tourism development. Tourism in Marine Environments 13(1):25-40

EC (2014) European Commission. Press release. Questions and Answers on the European strategy for coastal and maritime tourism. https://europa.eu/rapid/press-release_MEMO-14120_en.htm. Accessed 23 Oct 2019

EC (2019) European Commission. Maritime Affairs, Blue Growth. https://ec.europa.eu/maritimeaffairs/policy/blue_growth_en. Accessed 23 Oct 2019

Ertör I, Hadjimichael ME (2020) Blue degrowth and the politics of the sea: rethinking the blue economy. Sustain Sci 15(1):1-10. https://doi.org/10.1007/s11625-019-00772-y

Flyvbjerg B (2005) Five misunderstandings about case-study research. Stud Socjol 2:41-69

Force A, Manuel-Navarrete D, Benessaiah K (2018) Tourism and transitions toward sustainability: developing tourists' pro-sustainability agency. Sustain Sci 13(2):431-445

Hampton MP, Jeyacheya J, Lee D (2018) The political economy of dive tourism: precarity at the periphery in Malaysia. Tour Geograph 20(1):107-126

Hanna P, Wijesinghe S, Paliatsos I, Walker C, Adams M, Kimbu A (2019) Active engagement with nature: outdoor adventure tourism, sustainability and wellbeing. J Sustain Tour 1-19

Hoyt E (2001) Whale watching 2001: Worldwide tourism numbers, expenditures, and expanding socioeconomic benefits. FAO.

Hritz N, Cecil AK (2008) Investigating the sustainability of cruise tourism: a case study of Key West. J Sustain Tour 16(2):168-181

Job H, Paesler F (2013) Links between nature-based tourism, protected areas, poverty alleviation and crises-the example of Wasini Island (Kenya). J Outdoor Recreat Tour 1:18-28

Jordan EJ, Vogt CA (2017) Residents' perceptions of stress related to cruise tourism development. Tour Plan Dev 14(4):527-547

Jordan EJ, Spencer DM, Prayag G (2019) Tourism impacts, emotions and stress. Ann Tour Res 75:213-226

Kinseng RA, Nasdian FT, Fatchiya A, Mahmud A, Stanford RJ (2018) Marine-tourism development on a small island in Indonesia: blessing or curse? Asia Pac J Tour Res 23(11):1062-1072

Klein RA (2011) Responsible cruise tourism: Issues of cruise tourism and sustainability. J Hosp Tour Manag 18(1):107-116

Kontogeorgopoulos N (2005) Community-based ecotourism in Phuket and Ao Phangnga, Thailand: Partial victories and bittersweet remedies. J Sustain Tour 13(1):4-23

Lasso A, Dahles H (2018) Are tourism livelihoods sustainable? Tourism development and economic transformation on Komodo Island, Indonesia. Asia Pac J Tour Res 23(5):473-485

MacNeill T, Wozniak D (2018) The economic, social, and environmental impacts of cruise tourism. Tour Manag 66:387-404

Mallin MAF, Stolz DC, Thompson BS, Barbesgaard M (2019) In oceans we trust: conservation, philanthropy, and the political economy of the Phoenix Islands protected area. Mar Policy 107:103421

Marušić Z, Horak S, Tomljenović R (2008) The socioeconomic impacts of cruise tourism: a case study of Croatian destinations. Tour Mar Environ 5(2-3): 131-144

Mathis A, Rose J (2016) Balancing tourism, conservation, and development: a political ecology of ecotourism on the Galapagos Islands. J Ecotour 15(1):64-77 
Meletis ZA, Campbell LM (2009) Benevolent and Benign? Using environmental justice to investigate waste-related impacts of ecotourism in destination communities. Antipode 41(4):741-780

Mitchell RE, Reid DG (2001) Community integration: Island tourism in Peru. Ann Tour Res 28(1):113-139

Mosedale J (2015) Critical engagements with nature: tourism, political economy of nature and political ecology. Tour Geograph 17(4):505-510

Nogué-Algueró BG (2020) Growth in the docks: ports, metabolic flows and socio-environmental impacts. Sustain Sci 15(1):11-30. https ://doi.org/10.1007/s11625-019-00764-y

Rizzi J, Gallina V, Torresan S, Critto A, Gana S, Marcomini A (2016) Regional risk assessment addressing the impacts of climate change in the coastal area of the Gulf of Gabes (Tunisia). Sustain Sci 11(3):455-476

Salazar NB (2012) Community-based cultural tourism: Issues, threats and opportunities. J Sustain Tour 20(1):9-22

Sánchez-Cañizares SM, Castillo-Canalejo AM (2014) Communitybased island tourism: the case of Boa Vista in Cape Verde. Int $\mathbf{J}$ Cult Tour Hosp Res 8(2):219-233

Seidl A, Guiliano F, Pratt L (2006) Cruise tourism and community economic development in Central America and the Caribbean: the case of Costa Rica. PASOS. Revista de Turismo y Patrimonio Cultural 4(2):213-224.
Sun X, Jiao Y, Tian P (2011) Marketing research and revenue optimization for the cruise industry: a concise review. Int J Hosp Manag 30(3):746-755

Surjan AK, Shaw R (2008) 'Eco-city' to 'disaster-resilient eco-community': a concerted approach in the coastal city of Puri, India. Sustain Sci 3(2):249-265

Thomas J, Harden A (2008) Methods for the thematic synthesis of qualitative research in systematic reviews. BMC Med Res Methodol 8(1):45

UN (2006) The International Forum for Social Development. Social Justice in an Open World. The Role of the United Nations. The Department of Economic and Social Affairs. Division for Social Policy and Development. ST/ESA/305. https://www.un.org/esa/ socdev/documents/ifsd/SocialJustice.pdf. Accessed 28 Oct 2019

Voyer M, Gladstone W, Goodall H (2012) Methods of social assessment in Marine Protected Area planning: is public participation enough? Mar Policy 36(2):432-439

Wood M (2002) Ecotourism: principles, practices and policies for sustainability. UNEP

Publisher's Note Springer Nature remains neutral with regard to jurisdictional claims in published maps and institutional affiliations. 